\title{
PENGARUH LOCUS OF CONTROL INTERNAL DAN PENDAPATAN TERHADAP LITERASI KEUANGAN MAHASISWA
}

\author{
Susanti, Pascasarjana Universitas Negeri Surabaya \\ new.susanti@yahoo.com
}

\begin{abstract}
ABSTRAK
Penelitian ini bertujuan untuk menganalisis pengaruh Locus of Control internal dan pendapatan terhadap literasi keuangan mahasiswa Fakultas Ekonomi di Universitas Negeri Surabaya baik secara parsial maupun simultan. Populasi dalam penelitian ini adalah Mahasiswa Fakultas Ekonomi Prodi S1 Pendidikan Akuntansi dan S1 Akuntansi di Universitas Negeri Surabaya tahun angkatan 2012-2014. Teknik pengambilan sampel yang digunakan dalam penelitian ini adalah proporsional area probability sampling. Sedangkan metode analisis menggunakan teknik analisis regresi linear berganda. Hasil analisis data menunjukkan bahwa secara parsial Locus of Control Internal berpengaruh signifikan positif terhadap literasi keuangan mahasiswa. Sedangkan pendapatan berpengaruh signifikan negatif terhadap literasi keuangan mahasiswa. Hasil analisis data secara simultan Locus of Control Internal dan pendapatan berpengaruh signifikan terhadap literasi keuangan mahasiswa Fakultas Ekonomi di Universitas Negeri Surabaya.
\end{abstract}

Kata Kunci: Locus of Control Internal, Pendapatan, Literasi Keuangan

\begin{abstract}
This study aimed to analyze the influence of internal Locus of Control and the income of students to the financial literacy of students of Faculty of Economics in Universitas Negeri Surabaya either partially or simultaneously. The population in this study is the Faculty of Economics Study Program S1 and S1 Accounting Accounting Education in Universitas Negeri Surabaya years 2012-2014. The sampling technique used in this research is proportional probability sampling area. While the method of analysis using multiple linear regression analysis. The results of data analysis showed that partially Internal Locus of Control has positive significant effect on the financial literacy of students. While income has significant negative effect on the financial literacy of students. The results of the analysis of simultaneous data Internal Locus of Control and earnings significantly influence the financial literacy of students of Faculty of Economics at the State University of Surabaya.
\end{abstract}

Keywords: Internal Locus of Control, income, Financial Literacy.

\section{PENDAHULUAN}

Perkembangan perekonomian pada saat ini sangat berkembang pesat, salah satunya di bagian keuangan. Dalam keadaaan seperti saat ini masyarakat di Negara berkembang salah satunya Indonesia diharuskan memiliki pengetahuan tentang keuangan serta pengelolaannya dengan baik. Masyarakat tidak berpikir panjang untuk membelanjakan uang yang mereka terima, apalagi jika mereka 
memiliki pendapatan yang cukup. Akan tetapi, banyak pula orang yang masih memiliki masalah keuangan meskipun pendapatan yang mereka terima cukup besar. Dalam kenyataan yang ada di masyarakat saat ini menunjukkan gaya hidup yang konsumtif dan tidak sesuai dengan pendapatan yang diterima, kondisi keuangan serta kurangnya pengetahuan dan cara pandang terhadap keadaan keuangan yang akhirnya dapat menyebabkan kegagalan finansial. Lusardi \& Mitchell (2006) menjelaskan bahwa literasi keuangan dapat diartikan sebagai pengetahuan keuangan dengan tujuan mencapai kesejahteraan. Pengertian dari literasi tersebut dapat dimaknai sebagai bentuk persiapan untuk menghadapi globalisasi, khususnya globalisasi dalam bidang keuangan.

Dari hasil observasi di Fakultas Ekonomi Universitas Negeri Surabaya, diketahui bahwa perilaku mahasiswa semakin konsumtif tanpa mempertimbangkan hal ke depan, seperti kegiatan yang banyak dilakukan mahasiswa dan masyarakat saat ini adalah sistem belanja online. Perilaku konsumtif mahasiswa ini tidak didasarkan lagi pada teori kebutuhan (need), tetapi didorong oleh hasrat (desire) dan keinginan (want). Bahri (2014) menjelaskan bahwa Pergeseran perilaku konsumsi masyarakat saat ini tidak untuk memenuhi kebutuhan tetapi didasarkan pada motivasi untuk mendapatkan tantangan, suatu sensasi, kegembiraan, sosialisasi, menghilangkan stress, memberikan pengetahuan baru tentang perkembangan trend baru dan model baru serta untuk menemukan barang yang baik dan bernilai bagi diri masyarakat. Maka tidak mengherankan apabila melihat grafik investasi dan saving masyarakat selalu bergerak turun dari waktu ke waktu.

Capuano \& Ramsay (2011) mengemukakan 6 (enam) kompetensi inti literasi keuangan, yaitu: kemampuan dasar seseorang dalam pengelolaan keuangan (money basic), pengalokasian pemasukan dan pengeluaran (budgeting), menabung dan merencanakan, pengetahuan tentang pinjaman (borrowing) dan pemahaman dalam pengelolaan hutang (debt literacy), memahami produk-produk keuangan dan investasi serta kemampuan siswa untuk melindungi dirinya sendiri dari resiko keuangan. Kompetensi tersebut harus dikuasai oleh mahasiswa, khususnya mahasiswa program studi S1 Pendidikan Akuntansi dan S1 Akuntansi.

Literasi keuangan dapat dipengaruhi oleh beberapa faktor salah satunya adalah Locus of Control, variabel ini merupakan aspek psikologis yang harus diperhatikan. Locus of Control pertama kali di kemukakan oleh Rotter (1966) seorang ahli teori pembelajaran ekonomi. Locus of Control adalah cara pandang seseorang terhadap suatu peristiwa apakah dia dapat atau tidak dapat mengendalikan peristiwa yang terjadi padanya. Locus of Control diorientasikan menjadi dua, yaitu Locus of Contro internal dan Locus of Control eksternal.

Rotter (1966) menyatakan bahwa Locus of Control internal merupakan cara pandang seseorang terhadap suatu peristiwa sebagai peristiwa yang dapat diramalkan, dan perilaku individu turut berperan didalamya. Maksudnya seseorang meyakini bahwa suatu keberhasilan atau kegagalan yang terjadi pada dirinya tergantung dari sikap, tanggung jawab pribadi dan merupakan hasil dari usahanya sendiri.

Mahasiswa merupakan salah satu komponen masyarakat yang memberikan pengaruh cukup besar terhadap perekonomian karena suatu saat mahasiswa akan memasuki dunia kerja dan harus bisa mandiri termasuk dalam masalah keuangan mereka. Setiap orang diharuskan memiliki pengetahuan tentang keuangan, karena 
akan memudahkan pada kegiatan yang dilakukan sehari-hari. Untuk itu, seseorang harus memiliki literasi keuangan agar terhindar dari masalah keuangan. Banyak mahasiswa menggunakan sumber dana yang mereka miliki sesuai keinginan tanpa membuat perincian dan penganggaran terlebih dahulu. Sehingga penggunaan keuangan mereka tidak terkontrol. Mereka sering tidak memperhatikan akan kepentingan di masa yang akan datang.

Literasi keuangan juga dapat dipengaruhi oleh pendapatan yang diterima. Pengertian pendapatan menurut Bowo (2011) pendapatan dapat diperoleh dari berbagai sumber, termasuk pendapatan yang diperoleh tanpa memberikan sesuatu kegiatan apapun yang diterima oleh seseorang. Pendapatan dapat diartikan pula sebagai sebuah hasil yang diperoleh dari jerih payah seseorang dalam bekerja dan dinilai dengan tingkat atau nilai tertentu. Menurut pendapat Sukirno (2006) pendapatan adalah jumlah penghasilan yang diterima oleh penduduk atas prestasi kerjanya selama satu periode tertentu, baik harian, mingguan, bulanan atau tahunan.

Mahasiswa Fakultas Ekonomi di Universitas Negeri Surabaya yang sebagian besar belum bekerja memperoleh pendapatan dari uang saku yang diterima dari orang tua. Dari hasil observasi, mahasiswa yang belum bekerja memperoleh uang saku dari orang tua dengan periode mingguan dan bulanan. Sebagian dari mahasiswa menerima uang saku melalui transfer bank karena tempat tinggal mereka jauh. Masalah yang dihadapi mahasiswa sangat kompleks pada segi pendapatan karena $80 \%$ mahasiswa memperoleh pandapatan hanya dari uang saku yang pemberian orang tua sedangkan 20\% mahasiswa memiliki pendapatan selain dari uang saku ada tambahan dari hasil bekerja dan beasiswa yang diterima. Masalah lain yang dihadapi mahasiswa adalah keterlambatan uang yang dikirimkan oleh orang tua sedangkan uang saku yang mereka miliki setiap bulannya tidak mencukupi untuk kebutuhan atau habis untuk kebutuhan yang tidak terduga. Selain kebutuhan yang tidak terduga, gaya hidup mahasiswa yang tinggi serta pola konsumsi yang boros dan tidak sesuai dengan pendapatan juga mempengaruhi kondisi keuangan mahasiswa.

Hasil dari penelitian terdahulu memiliki beberapa hasil yang berbeda tentang ketiga variabel yang telah dijelaskan di atas pada masing-masing penelitian. Ida \& Dwinta (2010) dalam penelitiannya menyatakan bahwa Financial knowledge memiliki pengaruh terhadap perilaku seseorang dalam mengatur keuangan (financial management behavior), akan tetapi Locus of Control dan personal income tidak mempunyai pengaruh terhadap perilaku seseorang dalam mengatur keuangan (financial management behavior). Hal ini dikarenakan responden yang diteliti adalah mahasiswa yang rata-rata belum memiliki penghasilan sendiri. Penelitian lain yang dilakukan oleh Kholillah (2013) menunjukkan hasil bahwa Locus of Control berpengaruh secara signifikan terhadap Financial Managemen Behavior sedangkan Financial Knowledge dan Income tidak berpengaruh secara langsung terhadap perilaku seseorang dalam mengatur keuangan (financial management behavior).

Literasi keuangan lebih dikenal dengan pengetahuan dalam pengaturan keuangan adalah salah satu perilaku ekonomi yang berkembang di masyarakat dan telah dijalani selama bertahun-tahun. Literasi keuangan merupakan kebutuhan dasar bagi setiap orang agar terhindar dari masalah keuangan, serta menjadi hal sangat penting seiring berkembangnya waktu. Capuano \& Ramsay (2011) 
mendefinisikan literasi keuangan adalah pengetahuan dan pemahaman tentang konsep-konsep keuangan sehingga menghasilkan kemampuan untuk membuat keputusan yang efektif tentang uang. Konsumsi masyarakat seperti saat ini mendorong seorang melakukan kegiatan konsumsi secara tidak rasional, salah satu diantaranya adalah mahasiswa. Hilgert et al. (2002) menyatakan bahwa diperlukan pengetahuan tentang bagaimana mengelola keuangan serta bagaimana teknik berinvestasi menjadi hal yang tidak dapat diabaikan lagi seperti waktuwaktu sebelumnya. Lebih jauh, Cude et al. (2006) menyatakan bahwa seiring berkembangnya instrumen keuangan, tidak diiringi oleh keinginan masyarakat untuk memulai berinvestasi, dan diduga salah satunya adalah rendahnya literasi keuangan.

Bukti empiris penelitian Ibrahim dkk. (2009) menemukan bahwa mayoritas mahasiswa di Malaysia memiliki pengetahuan keuangan (financial literacy) yang kurang tinggi, dan hal ini dapat menyebabkan tidak terarah dengan tepat pada saat membuat keputusan keuangan setiap hari. Kesulitan keuangan bukan hanya kurangnya dari pendapatan semata, kesulitan keuangan juga muncul jika terjadi kesalahan dalam pengelolaan keuangan seperti kesalahan dalam penggunaan kredit, dan tidak adanya perencanaan keuangan. Keterbatasan finansial dapat menyebabkan stress, dan rendahnya kepercayaan diri. Memiliki literasi keuangan, merupakan hal yang penting untuk mendapatkan kehidupan yang sejahtera dan berkualitas.

Sejumlah kompetensi inti yang disusun berdasarkan kajian teoritis dan empiris tentang literasi keuangan seseorang, maka dikatakan seseorang memiliki literasi keuangan jika memiliki kompetensi inti yang diungkapkan oleh Capuano \& Ramsay (2011), sebagai berikut: 1) Money basic yang meliputi kemampuan matematis dan keahlian seseorang dalam mengelola keuangan; 2) Budgeting yang meliputi kemampuan mengalokasikan pemasukan dan pengeluaran; 3) Saving dan planning yang meliputi kegiatan menyimpan uang yang telah diterima dan merencanakan pengeluaran uang yang akan dilakukan; 4) Borrowing dan debt literacy yang meliputi pengetahuan tentang perbedaan tipe-tipe pinjaman dan hipotik. Pada debt literacy membutuhkan pemahaman dalam mengurangi hutang dan pembayaran pinjaman; 5) Memahami produk-produk keuangan termasuk di dalamnya kemampuan menentukan apakah independent advice sudah atau akan diberikan, memahami resiko, pengembalian, tingkat bunga, inflasi dan lain-lain tentang keunggulan-keunggulan produk investasi; 6) Recourse dan self help yang meliputi kemampuan sesorang untuk melindungi dirinya sendiri dengan memahami prosedur penyelesaian masalah keuangan, termasuk di dalamnya kemampuan memahami informasi keuangan.

Istilah Locus Of Control muncul dalam teori social learning Rotter (1966) yang mengemukakan bahwa ada beberapa faktor yang mempengaruhi seseorang dalam belajar, salah satunya adalah expectancy yang artinya ekspektasi atau harapan seseorang bahwa reinforcement atau hasil akan muncul dalam situasi tertentu. Konsep expectancy inilah yang yang melahirkan istilah Locus of Control. Rotter (1966) mendefinisikan Locus of Control adalah konsep yang menjelaskan apakah seseorang merasa bahwa pengendalian hidup mereka berada dalam penguasaan mereka sendiri (internal Locus of Control) ataukah berada pada kekuasaan orang lain (eksternal Locus of Control). 
Dalam kaitannya dengan literasi keuangan, Locus of Control yang paling mempengaruhi adalah Locus of Control internal. Hal ini dibuktikan dari penelitian yang dilakukan oleh Kholillah (2013) dalam hasil penelitiannya menyebutkan bahwa Locus of Control berpengaruh signifikan terhadap financial management behavior. Dimana financial management behavior merupakan bagian dari literasi keuangan. Penelitian ini dilakukan di Surabaya dan masyarakat Surabaya yang menjadi responden dalam penelitian ini. Tanggapan responden terhadap variabel Locus of Control dalam kehidupan sehari-hari adalah bahwa masyarakat Surabaya cenderung internal Locus of Control. Ida \& Dwinta (2010) juga mengungkapkan bahwa Locus of Control eksternal akan cenderung kurang menunjukkan upaya yang dibutuhkan dalam membentuk literasi keuangan. Seseorang yang memiliki Locus Of Control eksternal lebih banyak menyandarkan harapannya pada orang lain, sedangkan seseorang yang memiliki Locus of Control internal lebih banyak menyandarkan harapannya pada diri sendiri dan lebih mendahulukan keahliannya dibandingkan dengan situasi yang menguntungkan.

Seseorang dengan Locus of Control internal tinggi kemungkinan besar juga akan berusaha untuk mempengaruhi orang lain serta berasumsi bahwa usahanya akan berhasil. Seseorang dengan Locus of Control internal juga akan lebih aktif dalam mencari informasi dan pengetahuan mengenai situasi mereka daripada seseorang dengan Locus of Control eksternal. Menurut Gershaw (1989) seseorang dengan Locus of Control internal percaya bahwa mereka sendiri yang menentukan nasibnya. Menurut Kholillah (2013) indikator yang digunakan untuk mengukur internal Locus of Control adalah kemampuan pengambilan keputusan, kemampuan dalam merubah hal-hal penting dalam hidup, tingkat keyakinan terhadap masa depan, kemampuan dalam menyelesaikan masalah keuangan dan peran diri dalam mengontrol keuangan sehari-hari.

Pendapatan dapat diartikan sebagai sebuah hasil yang diperoleh dari jerih payah seseorang dalam bekerja dan dinilai dengan tingkat atau nilai tertentu. Dalam memenuhi kebutuhan, setiap orang pada umumnya akan menyandarkan sumber pembelanjaan dari pendapatan yang diperolehnya dari bekerja. Pendapatan seseorang kebanyakan tidak hanya berasal dari satu sumber pekerjaan inti, tetapi terkadang ada beberapa pekerjaan sampingan yang dapat menghasilkan pendapatan tambahan. Pendapatan menurut Sukirno (2006) adalah jumlah penghasilan yang diterima oleh penduduk atas prestasi kerjanya selama satu periode tertentu, baik harian, mingguan, bulanan atau tahunan. Ada beberapa klasifikasi pendapatan menurut Sukirno (2006), yaitu: Pendapatan pribadi, pendapatan disposibel, dan pendapatan nasional.

Badan Pusat Statistik (2013) menggolongkan pendapatan penduduk menjadi empat golongan yaitu: 1) Golongan pendapatan rendah adalah apabila pendapatan rata-rata masyarakat Rp1.500.000,00 perbulan. 2) Golongan pendapatan sedang adalah apabila pendapatan rata-rata masyarakat antara Rp1.500.000 s.d. Rp2.500.000,00 perbulan. 3) Golongan pendapatan tinggi adalah apabila pendapatan rata-rata masyarakat antara Rp2.500.000,00 s.d. Rp3.500.000,00 perbulan. 4) Golongan pendapatan sangat tinggi adalah apabila pendapatan ratarata masyarakat lebih dari Rp3.500.000,00 perbulan.

Hilgert et al. (2002) dalam penelitiannya menyatakan responden dengan pendapatan yang lebih rendah kemungkinan melaporkan pembayaran tagihan mereka tidak tepat waktu dibandingkan dengan responden yang memiliki 
pendapatan lebih tinggi. Selain itu Aizcorbe et al. (2003) menemukan bahwa keluarga yang memiliki pendapatan lebih rendah memiliki kemungkinan yang relatif kecil untuk melaporkan perilaku menabung. Pendapatan akan menunjukkan perilaku pengelolaan keuangan seseorang yang lebih bertanggung jawab. Seseorang yang memiliki perilaku namajemen keuangan akan cenderung membuat anggaran, menghemat uang dan mengontrol kegiatan belanja mereka. Kholillah (2013) serta Ida \& Dwinta (2010) dalam penelitiannya menyatakan bahwa pendapatan tidak memiliki pengaruh yang signifikan terhadap financial management behavior. Hasil dari penelitian terdahulu dapat menjadi kajian dan mendorong keinginan untuk meneliti kembali tentang pengaruh pendapatan terhadap financial management.

Pendapatan tidak hanya berasal dari hasil kerja yang dilakukan oleh seseorang akan tetapi keuangan yang diperoleh dari berbagai sumber dapat disebut juga sebagai pendapatan. Misalnya sebagai seorang mahasiswa mereka mendapat uang bulanan dari orang tua, saudara dan kerabat juga dapat disebut sebagai pendapatan. Jadi dapat disimpulkan bahwa pendapatan adalah sumber daya keuangan yang dimiliki oleh seseorang dari berbagai sumber keuangan.

Berdasarkan pemaparan di atas maka tujuan penelitian ini antara lain: 1) untuk menganalisis pengaruh Locus of Control internal terhadap literasi keuangan mahasiswa Fakultas Ekonomi di Universitas Negeri Surabaya. 2) Untuk menganalisis pengaruh pendapatan terhadap literasi keuangan mahasiswa Fakultas Ekonomi di Universitas Negeri Surabaya. 3) Untuk menganalisis pengaruh Locus Of Control internal dan pendapatan terhadap literasi keuangan mahasiswa Fakultas Ekonomi di Universitas Negeri Surabaya.

\section{METODE PENELITIAN}

Pendekatan yang digunakan dalam penelitian ini adalah pendekatan kuantitatif. Penelitian ini menggunakan dua variabel bebas yaitu Locus Of Control internal (X1) dan pendapatan (X2), dan satu variabel terikat yaitu literasi keuangan (Y). Tujuan penelitian ini adalah pengujian hipotesis, yaitu penelitian yang menjelaskan fenomena yang terjadi dalam bentuk hubungan antar variabel. Tujuan khususnya adalah menguji pengaruh Locus of Control internal dan pendapatan terhadap literasi keuangan.

Populasi dalam penelitian ini adalah Mahasiswa Fakultas Ekonomi Prodi S1 Pendidikan Akuntansi dan S1 Akuntansi di Universitas Negeri Surabaya tahun angkatan 2012-2014. Teknik pengambilan sampel yang digunakan dalam penelitian ini adalah proporsional area probability sampling yaitu dengan mengambil wakil dari setiap tahun angkatan sebagai populasi dalam penelitian ini (Sugiyono, 2010), dengan asumsi bahwa masing-masing tahun angkatan memiliki hak serta kesempatan yang sama untuk dipilih menjadi sampel. Pengambilan sampel menggunakan perhitungan statistik menurut rumus Slovin (dalam Riduwan, 2010), sehingga diperoleh sampel sebanyak 228 responden.

Teknik pengumpulan data yang digunakan dalam penelitian ini adalah observasi, angket dan dokumentasi. Observasi pada penelitian ini dilakukan pada tahap awal dengan mengumpulkan informasi dan data yang tidak terbatas pada orang dan obyek tertentu. Angket yang digunakan dalam penelitian ini adalah angket tertutup. Angket tertutup digunakan untuk mendapatkan data primer 
mengenai hubungan antara variabel Locus of Control dan pendapatan serta variabel literasi keuangan. Data yang digunakan adalah data sekunder berupa dokumentasi dari Fakultas Ekonomi Universitas Negeri Surabaya untuk memperoleh informasi mengenai Profil dan struktur organisasi Fakultas Ekonomi.

Teknik analisis data menggunakan regresi linear berganda dengan menggunakan rumus:

$$
Y=\alpha+\beta_{1} X_{1}+\beta_{2} X_{2}+\text { ei }
$$

Terdapat dua uji statistic yang digunakan dalam penelitian ini yaitu uji $t$ dan uji F. Uji t digunakan untuk mengetahui ada atau tidaknya pengaruh Locus Of Control internal (X1) dan pendapatan (X2) secara parsial terhadap literasi keuangan $(\mathrm{Y})$. Uji $\mathrm{F}$ digunakan untuk mengetahui ada atau tidaknya pengaruh Locus of Control internal (X1) dan pendapatan (X2) secara simultan terhadap literasi keuangan $(\mathrm{Y})$.

\section{HASIL DAN PEMBAHASAN}

Uji asumsi klasik meliputi uji normalitas, uji multikolinieritas, uji heteroskedastisitas dan uji linieritas. Berdasarkan hasil uji normalitas dengan menggunakan Kolmogrov-Smirnov diperoleh nilai sebesar 0,044 dengan tingkat signifikansi 0,200 , berarti model berdistribusi normal karena tingkat signifikansinya $\geq 0,05$. Sedangkan untuk uji multikolinieritas diperoleh hasil bahwa nilai variance inflaton factor (VIF) seluruh variabel sebesar 1,013 yang berarti kurang dari 10, maka dapat disimpulkan bahwa seluruh variabel bebas pada penelitian ini tidak ada gejala multikolinearitas. Hasil uji heteroskedastisitas menggunakan rank spearman pada masing-masing variabel bebas menghasilkan $p$ $>0,05$. Hal ini berarti tidak terjadi heterokedastisitas sehingga variabel Locus of Control internal dan pendapatan dapat digunakan sebagai variabel yang mempengaruhi literasi keuangan mahasiswa Fakultas Ekonomi di Universitas Negeri Surabaya. Uji linieritas menunjukkan bahwa nilai signifikansi sebesar 0,145 lebih besar dari 0,05 yang artinya terdapat hubungan linear secara signifikan antara variabel Locus of Control Internal (X1) dengan variabel Literasi Keuangan (Y). Sedangkan nilai signifikansi sebesar 0,412 lebih besar dari 0,05 yang artinya terdapat hubungan linear secara signifikan antara variabel Pendapatan (X2) dengan variabel Literasi Keuangan (Y).

Model regresi yang diperoleh berdasarkan hasil penelitian dapat dituliskan dalam bentuk persamaan regresi sebagai berikut:

$$
\mathrm{Y}=19.883+1.487 \mathrm{X}_{1}-\mathbf{0 . 5 8 5 \mathrm { X } _ { 2 } + \mathrm { ei }}
$$

Berdasar persamaan regresi di atas dapat dijelaskan sebagai berikut: 1) Nilai $(\alpha)$ atau konstanta $=19.883$ artinya jika Locus of Control Internal (X1) dan Pendapatan (X2) sama dengan nol (0), maka nilai literasi keuangan (Y) sebesar 19.883. 2) Nilai $(\beta 1 \mathrm{X} 1)$ atau koefisien regresi $\mathrm{X} 1=1.487$ artinya setiap perubahan variabel Locus Of Control Internal (X1) akan berpengaruh signifikan positif terhadap literasi keuangan (Y) sebesar 1.487 dengan asumsi variabel Pendapatan (X2) tidak mengalami perubahan atau konstan. Koefisien regresi bernilai positif menunjukkan pengaruh yang searah, artinya apabila variabel Locus Of Control Internal (X1) meningkat satu satuan berdasarkan pengukuran yang dibuat dalam angket, maka literasi keuangan (Y) akan meningkat sebesar 1.487. 3) Nilai $(\beta 2 \mathrm{X} 2)$ atau koefisien regresi $\mathrm{X} 2=-0.585$ artinya bahwa perubahan 
variabel pendapatan (X2) berpengaruh signifikan negatif terhadap literasi keuangan (Y) sebesar -0. 585 dengan asumsi variabel Locus of Control Internal (X1) tidak mengalami perubahan atau konstan. Koefisien regresi bernilai negatif menunjukkan pengaruh yang berlawanan, artinya apabila variabel pendapatan (X2) meningkat satu satuan berdasarkan pengukuran yang dibuat dalam angket, maka literasi keuangan (Y) menurun sebesar 0,585.

Pertama, secara parsial nilai t-hitung pada variabel Locus Of Control Internal (X1) sebesar 22,372 dengan tingkat signifikansi sebesar 0,000 $<0,05$. Artinya Locus of Control Internal secara parsial berpengaruh signifikan positif terhadap literasi keuangan. Hal ini memberi pengertian bahwa Locus of Control Internal dan literasi keuangan memiliki hubungan yang searah. Semakin tinggi atau positif Locus of Control Internal yang dimiliki mahasiswa maka akan diiringi oleh meningkatnya atau semakain tinggi tingkat literasi keuangan mahasiswa. Demikian pula sebaliknya, semakin rendah Locus of Control Internal yang dimiliki mahasiswa maka semakain rendah pula tingkat literasi keuangan mahasiswa.

Hasil penelitian ini menunjukkan bahwa Locus of Control internal berpengaruh terhadap literasi keuangan mahasiswa sesuai dengan penelitian yang dilakukan oleh Kholillah (2013) dalam hasil penelitiannya menyebutkan bahwa Locus Of Control berpengaruh signifikan terhadap financial management behavior, dimana financial management behavior merupakan indikator dari literasi keuangan. Menurut Forte (2005) Locus of Control mengacu pada kondisikondisi dimana individu menunjukkan kesuksesan dan kegagalan mereka. Penelitian lain yang mendukung yaitu penelitian yang dilakukan Zaidi dan Muhsin (2011) mengemukakan bahwa seseorang yang memiliki Locus of Control internal memiliki motivasi yang tinggi dalam berpertasi dan melakukan segala hal.

Hasil penelitian terdahulu yang dilakukan Ida dan Dwinta (2010) mengungkapkan bahwa Locus of Control internal lebih banyak menyandarkan harapannya pada diri sendiri dan lebih mendahulukan keahliannya dibandingkan dengan situasi yang menguntungkan. Menurut Gershaw (1989) seseorang dengan Locus of Control internal percaya bahwa mereka sendiri yang menentukan nasibnya. Mereka juga percaya bahwa pengalaman mereka dikendalikan oleh keterampilan dan usaha mereka sendiri. Dalam pengelolaan keuangan Locus of Control internal juga berperan sangat penting, untuk merencanakan sebaik mungkin penggunaan keuangan mereka.

Locus of Control internal pada penelitian ini memiliki empat indikator yaitu kemampuan pengambilan keputusan, tingkat keyakinan terhadap masa depan, kemampuan menyelesaikan masalah keuangan dan peran diri dalam control keuangan sehari-hari. Berdasarkan jawaban yang diberikan responden pada indikator kemampuan pengambilan keputusan keuangan menunjukkan rerata dengan kategori tinggi yang artinya mahasiswa memiliki kemampuan yang baik dalam pengambilan keputusan keuangan sehari-hari. Selanjutnya adalah indikator tingkat keyakinan terhadap masa depan menunjukkan rerata dengan kategori tinggi yang artinya mahasiswa memiliki tingkat keyakinan yang tinggi terhadap masa depan, karena mereka sadar bahwa masa depan mereka berada pada usaha yang mereka dilakukan mulai dari saat ini. Indikator ketiga adalah kemampuan menyelesaikan masalah keuangan menunjukkan rerata dengan kategori tinggi yang artinya mahasiswa memiliki kemampuan yang baik dalam menyelesaikan 
masalah keuangan yang dihadapi dengan mencari berbagai alternatif solusi yang tepat untuk menyelesaikan masalah tersebut. Dan yang terakhir adalah indikator peran diri dalam control keuangan sehari-hari menunjukkan rerata dengan kategori tinggi yang artinya mahasiswa memiliki peran yang baik dalam mengontrol keuangan mereka sehari-hari sehingga literasi keuangan yang ditunjukkan juga semakin baik.

Berdasarkan uraian di atas maka dapat disimpulkan bahwa Locus of Control internal yang dimiliki mahasiswa baik maka literasi keuangan yang dimiliki juga akan semakin baik. Hal ini dikarenakan Locus of Control internal mahasiswa dapat mempengaruhi perilaku keuangan dan membentuk literasi keuangan mahasiswa menjadi lebih baik dibandingkan dengan mahasiswa yang memiliki Locus Of Control eksternal.

Kedua, nilai t-hitung pada variabel pendapatan (X2) sebesar -2,182 dengan tingkat signifikansi sebesar $0,030<0,05$. Artinya pendapatan secara parsial berpengaruh signifikan negatif terhadap literasi keuangan mahasiswa Fakultas Ekonomi di Universitas Negeri Surabaya. Ini berarti bahwa semakin tinggi pendapatan yang dimiliki mahasiswa maka akan diiringi oleh menurunnya tingkat literasi keuangan mahasiswa.

Hasil penelitian ini berbanding terbalik dengan hasil penelitian yang dilakukan oleh Hilgert et al. (2002), dalam penelitiannya menyatakan responden dengan pendapatan yang lebih rendah kemungkinan melaporkan pembayaran tagihan mereka tidak tepat waktu dibandingkan dengan responden yang memiliki pendapatan lebih tinggi. Artinya seseorang yang memiliki pendapatan rendah kurang memperhatikan ketepatan dalam membayar tagihan atau tingkat literasi keuangan yang dimiliki tergolong rendah berbeda dengan seseorang yang memiliki pendapatan tinggi, mereka lebih mampu mengelola keuangan mereka dengan baik. Penelitian ini didukung pula oleh penelitian yang dilakukan Aizcorbe et al. (2003), menemukan bahwa keluarga yang memiliki pendapatan lebih rendah memiliki kemungkinan yang relatif kecil untuk melaporkan perilaku menabung. Hal ini dikarenakan keluarga yang memiliki pendapatan rendah, cenderung menggunakan pendapatan tersebut untuk berbelanja kebutuhan mereka tanpa menyisihkan untuk ditabung terlebih dahulu.

Hasil ini berbeda dengan hasil penelitian yang dilakukan oleh Kholillah (2013) serta Ida \& Dwinta (2010) dalam penelitiannya menyatakan bahwa pendapatan tidak memiliki pengaruh yang signifikan terhadap financial management behavior. Perbedaan antara hasil penelitian yang dilakukan oleh Kholillah (2013) serta Ida \& Dwinta (2010) dengan hasil penelitian saat ini adalah responden yang dijadikan sebagai objek penelitian berbeda. Dalam penelitian yang dilakukan oleh Kholillah (2013) serta Ida \& Dwinta (2010) sebagian besar individu yang diteliti belum memiliki penghasilan tetap. Sedangkan responden yang menjadi objek penelitian saat ini memiliki penerimaan atau pendapatan tetap baik mahasiswa yang memperoleh pendapatan dari uang saku yang diberikan orang tua setiap bulan maupun pendapatan dari hasil bekerja, beasiswa dan berwirausaha.

Pendapatan dapat diartikan sebagai sebuah hasil yang diperoleh dari jerih payah seseorang dalam bekerja dan dinilai dengan tingkat atau nilai tertentu. Dalam memenuhi kebutuhan, setiap orang pada umumnya akan menyandarkan sumber pembelanjaan dari pendapatan yang diperolehnya dari bekerja. Bowo 
(2011) juga menyebutkan bahwa pendapatan dapat diperoleh dari berbagai sumber, termasuk pendapatan yang diperoleh tanpa memberikan sesuatu kegiatan apapun yang diterima oleh seseorang. Sesuai teori yang diungkapkan oleh ekonom John Maynard Keynes adalah hubungan yang seiring dengan kenaikan pendapatan dan konsumsi tidak pada tingkat yang sama. Pendapatan relatif menentukan tabungan seseorang atau keluarga dan konsumsi berdasarkan pendapatan keluarga dalam kaitannya dengan orang lain.

Berdasarkan penelitian yang dilakukan seluruh mahasiswa Fakultas Ekonomi di Universitas Negeri Surabaya memperoleh pendapatan tidak hanya dari uang saku yang diberikan orang tua melainkan juga dari hasil bekerja, beasiswa dan berwirausaha. Hasil penelitian ini menunjukkan hasil bahwa semakin tinggi tingkat pendapatan yang diterima mahasiswa maka semakin tinggi pula keinginan untuk membelanjakan uang tersebut. Keinginan mahasiswa dalam membelanjakan pendapatan yang diterima tanpa mengontrol keuangan dapat menyebabkan kegagalan dalam mengelola keuangan dan berdampak menurunnya tingkat literasi keuangan. Hal ini disebabkan oleh gaya hidup mahasiswa yang konsumtif dan pergaruh dalam pergaulan sehari-hari.

Gaya hidup mahasiswa yang konsumtif menjadikan mahasiswa Fakultas Ekonomi terbiasa membelanjakan uang atau pendapatan yang diterima tanpa memperhatikan dampak yang akan terjadi. Gaya hidup konsumtif didukung dengan adanya kemajuan teknologi, seperti yang sedang ramai saat ini adalah sistem belanja online. Selain itu letak Fakultas di Universitas Negeri Surabaya dekat dengan pusat perbelanjaan serta sentra kuliner. Pergaulan mahasiswa seharihari dengan teman-temannya ataupun diluar lingkungan perkuliahan juga dapat menjadi alasan kegagalan finansial. Mahasiswa cenderung ingin menjalin kerjasama yang baik dengan teman, hal tersebut ditunjukkan mahasiswa dengan membeli barang yang sama meskipun hal tersebut kurang memiliki manfaat yang berarti. Menurut Owen (2003) menyatakan bahwa untuk memiliki ketrampilan mengelola keuangan dengan baik, anak harus dilatih dalam hal menabung, mengelola uang saku, melakukan pekerjaan ringan diluar rumah, berderma dan berinvestasi.

Ketiga, secara simultan hasil uji $\mathrm{F}$ yang dilakukan menunjukkan bahwa variabel Locus of Control Internal dan pendapatan secara simultan atau bersamasama berpengaruh signifikan positif terhadap literasi keuangan, hal tersebut terlihat dari hasiluji F yaitu nilai Fhitung sebesar 250,303 dengan signifikansi 0.000 kurang dari $5 \%$. Besarnya pengaruh variabel Locus of Control Internal dan pendapatan secara simultan terhadap literasi keuangan dapat dilihat dari koefisien determinasi (R Square) yaitu sebesar 0,690 menunjukkan bahwa literasi keuangan dipengaruhi oleh Locus of Control Internal dan pendapatan sebesar 69\% sedanggkan $31 \%$ dipengaruhi oleh faktor-faktor lain selain variabel dalam penelitian ini.

Hilgert et al. (2002) menyatakan bahwa diperlukan pengetahuan tentang bagaimana mengelola keuangan serta bagaimana teknik berinvestasi menjadi hal yang tidak dapat diabaikan lagi seperti waktu-waktu sebelumnya. Lebih jauh, Cude et al. (2006) menyatakan bahwa seiring berkembangnya instrumen keuangan, tidak diiringi oleh keinginan masyarakat untuk memulai berinvestasi,dan diduga salah satunya adalah rendahnya literasi keuangan. Pengelolaan keuangan juga dipengaruhi oleh besar atau kecilnya pendapatan yang 
diperoleh seseorang. Besar kemungkinan individu yang memiliki pendapatan besar dapat lebih bertanggung jawab dalam pengelolaan keuangan. Hal ini sejalan dengan pendapat Hilgert et al (2002) menyatakan responden dengan pendapatan yang lebih rendah kemungkinan melaporkan pembayaran tagihan mereka tidak tepat waktu dibandingkan dengan responden yang memiliki pendapatan lebih tinggi.

Berdasarkan hasil penelitian diperoleh hasil bahwa terdapat hubungan Locus of Control internal dan pendapatan yang mempengaruhi literasi keuangan mahasiswa Fakultas Ekonomi di Universitas Negeri Surabaya. Hal ini terjadi karena naiknya pendapatan yang disertai dengan Locus of Control internal yang baik maka akan membentuk literasi keuangan yang baik pula. Karena seseorang yang memiliki Locus of Control internal dapat merencanakan sebaik mungkin penggunaan keuangan mereka agar dapat bermanfaat di masa yang akan datang. Pada dasarnya orang yang memiliki Locus of Control internal yakin bahwa dirinya bertanggung jawab dan memiliki kontrol atas kejadian-kejadian yang dialaminya

\section{SIMPULAN}

Simpulan dari penelitian ini antara lain: 1) Terdapat pengaruh Locus Of Control internal terhadap literasi keuangan mahasiswa Fakultas Ekonomi di Universitas Negeri Surabaya. Hal ini berarti Locus of Control internal secara parsial berpengaruh signifikan positif terhadap literasi keuangan mahasiswa. Semakin baik atau tinggi tingkat Locus of Control Internal mahasiswa akan berpengaruh terhadap tingginya tingkat literasi keuangan yang dimiliki oleh mahasiswa. Locus of Control internal dapat mempengaruhi perilaku keuangan dan membentuk literasi keuangan mahasiswa menjadi lebih baik. 2) Terdapat pengaruh pendapatan terhadap literasi keuangan mahasiswa Fakultas Ekonomi di Universitas Negeri Surabaya. Hal ini berarti pendapatan secara parsial berpengaruh signifikan negatif terhadap literasi keuangan mahasiswa. Artinya semakin besar pendapatan yang diterima oleh mahasiswa maka akan berdampak pada tingkat literasi keuangan mahasiswa yang semakin menurun. Hal tersebut ditunjukkan dengan perilaku keuangan mahasiswa yaitu semakin tinggi tingkat pendapatan yang mereka terima maka keinginan mahasiswa untuk membelanjakan uang juga semakin tidak terkontrol dikarenakan gaya hidup konsumtif serta pergaulan mahasiswa dengan teman-teman di dalam maupun di luar lingkungan perkuliahan. 3) Terdapat pengaruh Locus of Control Internal dan pendapatan terhadap literasi keuangan mahasiswa Fakultas Ekonomi di Universitas Negeri Surabaya. Hal ini berarti Locus of Control Internal dan pendapatan secara simultan memiliki pengaruh signifikan positif terhadap literasi keuangan mahasiswa. hasil temuan ini menunjukkan bahwa perubahan tingkat pendapatan yang disertai adanya Locus of Control Internal yang baik pada diri mahasiswa dapat membentuk tingkat literasi keuangan yang baik pula.

Sedangkan saran yang dianjurkan peneliti antara lain: 1) Bagi mahasiswa untuk tetap belajar dan menumbuhkan perilaku keuangan yang positif serta mengumpulkan informasi tentang bidang keuangan karena akan sangat berguna dalam kehidupan sehari-hari dan sebagai bekal menuju persaingan di dunia kerja. Mahasiswa disarankan untuk menumbuhkan Locus of Control pada diri masing- 
masing karena dapat mempengaruhi perilaku keuangan dan membentuk literasi keuangan mahasiswa menjadi lebih baik. 2) Bagi peneliti selanjutnya disarankan untuk memperluas penelitian dengan cara menambah faktor-faktor lain yang dapat mempengaruhi literasi keuangan, agar penelitian tentang literasi keungan dapat berkembang. Faktor lain yang mungkin dapat digunakan sebagai alternatif penelitian adala pendidikan keuangan keluarga, pembelajaran di perguruan tinggi, pendidikan dan pendapatan orang tua serta jenis kelamin.

\section{DAFTAR RUJUKAN}

Aizcorbe, A. M., Kennickell, A. B., \& Moore, K. B, 2003. Recent Changes in U.S. Family Finances: Evidence from the 1998 and 2001 Survey of Consumer Finances. Federal Recerve Bulletin, 1-32.

Badan Pusat Statistik. 2013. Susenas Jatim. Jawa Timur: BPS

Bahri, Andi. 2014. Etika Konsumsi dalam Perspektif Ekonomi Islam. Jurnal Studia Islamika, 347-370.

Bowo. 2011. Akuntansi Biaya: bowosukses, (Online), (http://www.Akuntansibiaya.blogspot.com), diakses 5 April 2015.

Capuano, A. \& Ramsay, I. 2011. What Causes Suboptimal Financial Behaviour? An Exploration of Financial Litercy, Social Influences and Behavioural Economics. Melbourne: Corporate Law and Securities Regulation.

Cude, B. J. et all. (2006). College Student and Financial Literacy: What They Know and what Need to Learn. Eastern Family Economics and Resource Management Association, 102-109.

Forte, A. 2005. Locus Of Control and the Moral Reasoning of Managers. Journal of Bussiness Ethics, 65-77.

Gershaw, D. A. 1989. Locus Of Control , (Online), (http://virgil.azwestern.edu/dag/lol/ControlLocus,html), diakses 15 April 2015.

Hilgert, M. A., Hogarth, J. M., \& Beverly, S. G. 2002. Household Financial Management: the Connection between Knowledge and Behavior. Federal Reserve Bulletin, 309-322.

Ibrahim, D., Harun, R. I., \& Zuraidah. M. 2009. A Study on Financial Literacy of Malaysian Degree Students. Cross-Cultural Communication, 51-59.

Ida, D., \& Cinthia, Y. 2010. Pengaruh Locus Of Control , financial knowledge, income terhadap financial management behavior. Jurnal Bisnis dan Akuntansi, 131-144.

Kholillah, N. 2013. Studi Financial Management Behavior pada Masyarakat Surabaya. Journal of Business and Banking, 69-80.

Lusardi, A., \& Mitchell, O. S. 2006. Financial Literacy and Planning: Implications for Retirement Wellbeing. 1-33.

Owen, D. 2003. Melejitkan kecerdasan Financial Anak. Terjemahan oleh Lovely. Bandung: Kaifa.

Riduwan. 2010. Skala Pengukuran Variabel-variabel Penelitian. Bandung: Alfabeta

Rotter, J. B. 1966. Generalized Expectancies for Internal Versus External Control of Reinforcement. Psychological Monographs: General and Applied, vol.80 no. $1: 1-27$.

Sugiyono. 2010. Statistika Untuk Penelitian. Bandung: Alfabeta. 
Sukirno, S. 2006. Ekonomi Pembangunan: Proses, Masalah dan Dasar Kebijakan. Jakarta: Kencana Prenada Media Group.

Zaidi, I. H., \& Mohsin, M. N. 2011. Locus Of Control in Graduation Student. International Journal of Psychological Research, 15-20 